\title{
MEMBANGUN NIAT PENGUNJUNG UNTUK BERWISATA DI GUNUNG API PURBA NGELANGGERAN GUNUNGKKIDUL
}

Rendi Ajib Dhiastama ${ }^{1}$

IBN Udayana ${ }^{2}$

Ambar Lukitaningsih ${ }^{3}$

Manajemen, Fakultas Ekonomi, Universitas Sarajanawiyata Tamansiswa,

\begin{tabular}{l}
\hline Info Artikel \\
\hline Sejarah Artikel: \\
Diterima : 28 Mei 2021 \\
Disetujui : 1 Juni 2021 \\
Dipublikasikan : 2 Juni 202 \\
\hline Keywords: \\
Kualitas Pelayanan, \\
Kualitas Informasi, \\
Kualitas Sistem, \\
Kepercayaan Dan \\
Minat Berkunjung \\
\hline
\end{tabular}
\begin{abstract}
$\underline{\text { Abstrak }}$
Penelitian bertujuan untuk, mengetahui pengaruh kualitas pelayanan, kualitas informasi, kualitas sistem dan kepercayaan terhadap minat berkunjung di obyek wisata Gunung Api Purba Gunung Kidul, Dengan mengetahui besarannya pengaruh dari variabel yang diteliti, diharapkan dapat memberikan rekomendasi yang baik untuk memberikan strategi dalam peningkatan Minat wisatawan untuk berkunjung. Metode dalam penelitian ini menggunakan metode Accidental Sampling. Penelitian ini merupakan penelitian kuantitatif, sampel dalam penelitian ini 92 Wisatawan yang berkunjung di Obyek wisata Gunung api Purba. Teknik pengambilan data dilakukan dengan menggunakan kuesioner. Hasil dari penelitian ini yaitu, ada pengaruh positif dan signifikan kualitas pelayanan terhadap minat berkunjung, kualitas informasi tidak pengaruh signifikan terhadap minat berkunjung, Kualitas sistem berpengaruh signifikan terhadap Minat berkunjung, Kepercayaan tidak berpengaruh signifikan terhadap minat berkunjung. Secara simultan kualitas pelayanan, kualitas informasi, kualitas sistem dan kepercayaan berpengaruh secara simulyan terhadap minat berkunjung.
\end{abstract}

Kata kunci: Kualitas Pelayanan, Kualitas Informasi, Kualitas Sistem, Kepercayaan Dan Minat Berkunjung

\begin{abstract}
The research aims to determine the effect of service quality, information quality, system quality and trust on the interest in visiting the Gunung Kidul Purba Volcano tourism object. By knowing the magnitude of the influence of the variables studied, it is hoped that it can provide good recommendations to provide strategies for increasing tourist interest. to visit. The method in this study using the Accidental Sampling method. This research is a quantitative study, the sample in this study is 92 tourists who visit the ancient volcano tourism object. The data collection technique is done by using a questionnaire. The results of this study are that there is a positive and significant effect of service quality on visiting interest, information quality has no significant effect on visiting interest, system quality has a significant effect on visiting interest, trust does not have a significant effect on visiting interest. Simultaneously, service quality, information quality, system quality and trust have a simultaneous effect on visiting interest.
\end{abstract}

Keywords: Quality of service, quality of information, quality of system, trust and interest in visiting. 


\section{PENDAHULUAN}

Pariwisata adalah suatu proses kepergian sementara dari seseorang atau lebih menuju tempat lain di luar tempat tinggalnya. Dorongan kepergiannya dalah karena berbagai kepentingan, baik karena kepentingan ekonomi, social, kebudayaan, politik, agama, kesehatan maupun kepentingan lain seperti karena sekedar ingin tahu, menambah pengalaman ataupun belajar. Pariwisata muncul karena adanya kebutuhan dan keinginan seseorang maupun kelompok orang untuk menghilangkan kepenatan, memenuhi kebutuhan rohani, dan lainlain. Pariwisata selalu berkembang tidak hanya menjadi sebuah kegiatan namun juga memiliki prospek bisnis yang cukup menjajikan. Dengan begitu, lalu munculah berbagai objekobjek wisata sebagai alat pemenuh kebutuhan pariwisata yang menawarkan berbagai macam hiburan dan pengetahuan baru bagi pengunjung atau wisatawan.

Seiring dengan kemajuan pariwisata, wisatawan juga mengalami perubahan baik dari pola pikir maupun minat dan ketertarikannya. Wisatawan pada saaat ini telah berpikir kritis dan tidak lagi hanya terfokus pada pencarian kesenangan semata, namun mereka juga telah mulai peduli pada pengembangan Pendidikan, budaya, lingkungan, sejarah, alam dan kelestariannya. Keprihatinan atas dasar kerusakan alam dan lingkungan yang terjadi di berbagai tempat telah membentuk trend wisata baru yang menggunakan konsep keberlanjutan dan bertanggung jawab. Wisatawan mulai beralih ke dalam jenis wisata yang lebih tinggi, seperti: menikmati produk atau kreasi budaya (Culture) dan peninggalan sejarah (heritage), serta ekowisata (Nature) dari suatu daerah atau negara. Sebagai negara yang yang memiliki berbagai peninggalan sejarah, budaya yang beragam dan unik, serta kekayaan keindahan alam yang hampir tersebar diseluruh pelosok daerah, tentu saja Indonesia memiliki peluang yang sangat besar untuk menjadi tujuan pariwisata.

Indonesia memiliki potensi keindahan yang dan kekayaan alam yang sangat bernilai tinggi dalam pasar industri pariwisata khususnya dalam sektor wisata alam atau ekowisata. Salah satu daerah di Indonesia yang memiliki destinasi ekowisata atau wisata alam yang cukup banyak yaitu terdapat di Daerah Istimewa Yogyakarta, tepatnya berada di kabupaten Gunung Kidul.

Kabupaten Gunung Kidul mempunyai slogan HANDAYANI yang merupakan singkatan dari (Hijau - Aman - Normatif - Dinamis - Yakin - Asah Asih Asuh - Nilai Tambah Indah) mulai menata diri dan mempromosikan daerahnya lewat berbagai objek wisata yang kebanyakan merupakan wisata berbasis alam. Gunung Kidul mendapatkan predikat sebagai daerah salah satu daerah pariwisata terpopuler di Indonesia yang mampu memberikan kontribusi terhadap pendapatan daerah (Jamalina \& Wardani, 2017).

Destinasi wisata yang ada di kabupaten Gunung Kidul terhitung kurang lebih 67 destinasi yang terdiri dari wisata pantai, goa, desa wisata, gunung, telaga dan kebun buah (Sari, 2016). Dari jumlah tersebut, salah satu destinasi favorit yang banyak dikunjungi oleh wisatawan adalah obyek wisata Gunung Api Purba Nglanggeran.

Gunung Api Purba Nglanggeran terletak di Kawasan Baturagung di bagian utara Kabupaten Gunung 
Kidul, tepatnya di Desa Nglanggeran, Kecamatan Patuk, Gunungkidul, D.I Yogyakarta. Daerah ini terbentuk dari gugusan material vulkanik tua dan geologi yang sangat unik bernilai ilmiah tinggi sehingga menjadikan Gunung Api Purba Nglanggeran memiliki bentang alam yang sangat indah. Gunung Api Purba memiliki sektor wisata yang beragam, selain sector wisata alam dengan fokus keindahan alamnya. Wisatawan juga dapat mencoba serta menikmati sector wisata lainnya seperti: wisata budaya, wisata religi, hingga adventure tourism yang terdiri dari kegiatan berkemah, outbond, melihat sunset dan sunrise, panjat tebing (climbing) dan rappelling, tracking (Jelajah gunung dan susur gua), flying fox, hingga sector eduwisata bidang lingkungan, seni dan budaya, serta lokasi Community Gathering. Kawasan wisata Gunung Api Purba Nglanggeran Dengan gugusan Vulkanik dan memeiliki karakteristik geologi yang sangat unik tersebut kemudian dijagokan sebagai taman bumi atau Geopark, dan UNESCO melalui perwakilannya pada tahun 2010 lalu telah mengakui potensi kawasan ini karena memiliki nilai ekologi dan warisan budaya (Culture Heritages) serta berfungsi sebagai daerah konservasi, edukasi, dan sustainable development (www.gunungapipurba.com). Maka dari itu Gunung Api Purba merupakan salah satu referensi tempat wisata yang sangat cocok untuk dikunjungi.

Berdasarkan data diatas, dapat dikatakan bahwa pengelolaan pada obyek wisata Gunung Api Purba Nglangeran termasuk dalam kategori yang baik, sebab dibuktikan dengan trend yang cukup baik dari jumlah wisatawan yang berlibur atau datang berwisata ke Gunung Api Purba
Nglanggeran. Jumlah pengunjung terbanyak yang datang di Gunung Api Purba Nglanggeran berada pada tahun 2014, namun setelah itu mengalami penurunan yang cukup drastis pada tahun-tahun berikutnya. Penurunan tingkat kunjungan tersebut didominasi oleh wisatawan domestik sedangkan kunjungan dari wisatawan mancanegara selalu mengalami kenaikan di setiap tahunnya. Dari data diatas dan dengan melihat trend penurunan pengunjung Gunung Api Purba Nglanggeran ini dapat dikatakan bahwa perilaku konsumen atau wisatawan bisa saja berubah-ubah sesuai dengan kebutuhan, keingian, ataupun faktor lain yang ada di dalam lingkup perusahaan atau organisasi dalam hal ini yaitu pengelola objek wisata Gunung Api Purba Nglanggeran. Dalam pengembangan destinasi wisata, terdapat beberapa masalah utama yang harus dihadapi, diantaranya perubahan iklim dan bencana alam, pemberdayaan masyarakat di daerah destinasi, kualitas SDM, serta iklim usaha yang tidak kondusif (Jamalina \& Wardani, 2017).

Usaha/perusahaan Mikro dan Kecil merupakan salah satu kegiatan ekonomi yang tumbuh subur di D.I. Yogyakarta. Berdasarkan Survei IMK 2018 Tahunan terdapat 91.328 usaha/perusahaan yang tersebar di seluruh kabupaten/kota di D.I. Yogyakarta. Dari jumlah tersebut, sebanyak 91.328 usaha/perusahaan atau 94,76 persen merupakan industri mikro, sedangkan sisanya merupakan industri kecil. Modal minim, fleksibilitas dalam menjalankan usaha, produk/jasa yang dihasilkan dekat dengan kebutuhan masyarakat, serta pemanfaatan sumber daya lokal menjadi ciri khas yang mendukung berkembangnya usaha ini. Jumlah 
usaha IMK menurut kabupaten/kota, terlihat bahwa Kabupaten Bantul Yogyakarta memiliki jumlah usaha IMK terbesar yang mencapai 37.464 usaha atau menguasai sebesar 33,06 persen dari total usaha IMK di D.I. Yogyakarta. Pada posisi kedua, sebanyak 29.599 usaha/perusahaan IMK terdapat di Kabupaten Sleman atau sebesar 26,09 persen. Kabupaten Gunungkidul, Kulon Progo, serta Kota Yogyakarta menempati posisi berikutnya dengan jumlah usaha/perusahaan IMK masing-masing sebesar 19.808 usaha, 19.338 usaha, dan 7.221 usaha. Pada tahun 2018, usaha/perusahaan IMK menyerap tenaga kerja sebesar 216.803 orang.

Menurut (Schiffman, 2007) Perilaku konsumen adalah proses yang dilalui oleh seseorang dalam mencari, membeli, menggunakan, mengevaluasi, dan bertindak Pasca konsumsi produk, jasa maupun ide yang diharapkan bisa memenuhi kebutuhannya. Logikanya semakin menarik suatu produk yang ditawarkan maka konsumen akan semakin tertarik untuk mengkonsumsi atau menggunakan barang tersebut. Dengan demikian, jika dikaitkan dengan pengelolaan Obyek wisata Gunung Api Purba Nglanggeran demi meningkatkan jumlah kunjungan serta tetap menjaga trend baik pariwisata pengelola harus benar-benar memahami perilaku konsumen yang berkaitan dengan peningkatan kepuasan konsumennya.

Ada banyak faktor yang mempengaruhi perilaku wisatawan, baik itu wisatawan domestik ataupun mancanegara dalam menentukan objek wisata yang akan dikunjungi. (Berkowitz \& Heimer, 1989) menjelaskan bahwa ada 4 faktor yang mempengaruhi keputusan konsumen. Faktor tersebut adalah marketing mix, social kultural, psikologi, dan situasi. Dari berbagai situasi, konsumen atau wisatawan dihadapkan dengan berbagai pertimbangan mengenai halhal yang berkaitan dengan objek wisata yang akan dikunjungi. Maka dari itu, dalam hal ini pengelola menjadi penentu utama yang memegang kendali dan harus memberikan kebijakan yang baik guna memberikan impact yang baik pula. Dengan membuat system, informasi, serta pelayanan yang baik maka secara tidak langsung akan memberikan rasa kepercayaan wisatawan untuk datang berwisata.

Untuk menjadi tempat wisata yang senantiasa diminati dan menjadi yang terbaik dari sektor industri ekowisata lainnya, pengelola Gunung Api Purba Nglanggeran harus fokus di berbagai aspek wisata. Selain kondisi alam yang indah perlu juga didukung dengan fasilitas dan pelayanan yang baik dari pengelola wisata dan juga masyarakat setempat. Terhitung dalam beberapa tahun terakhir terjadi penurunan jumlah pengunjung yang cukup signifikan, hal ini tentu saja disebabkan dari berbagai aspek yang ada dalam objek wisata Gunung Api Purba Nglanggeran. Beberapa aspek penting yang harus dibenahi yaitu antara lain: Kualitas pelayanan, Kualitas Sistem, Kualitas informasi serta kepercayaan.

Menurut (Kotler, 2012) Kualitas pelayanan merupakan totalitas dari bentuk karakteristik barang dan jasa yang menunjukkan kemampuannya untuk memuaskan kebutuhan pelanggan, baik yang nampak jelas maupun yang tersembunyi. Bagi perusahaan yang bergerak di sektor jasa, pemberian pelayanan yang berkualitas pada pelanggan merupakan hal mutlak yang harus dilakukan apabila perusahaan ingin mencapai 
keberhasilan. Dengan penjelasan tersebut, dapat dikatakan bahwa pengelola Gunung Api Purba Nglanggeran mengalami penurunan dalam aspek service quality sehingga berpengaruh cukup signifikan dalam berkurangnya jumlah pengunjung yang datang. Menurunnya kualitas pelayanan yang diberikan oleh pengelola bagi para wisatawan ini juga berkaitan dengan system quality dan information quality yang ada di Gunung Api Purba Nglanggeran.

Heru Purwanto, menurunnya jumlah wisatawan yang berkunjung di Gunung Api Purba Nglanggeran disebabkan juga dari system pelayanan yang berubah seperti dengan menaikan harga ticketing serta mengalihkan seluruh fokus profit dengan tidak mengutamkan pendapatan dari sector parkir pengunjung. Selain itu, pengelola juga memberlakukan penekanan jumlah wisatawan yang berkunjung karena pada tahun sebelumnya wisatawan sempat membludak dan kondisi alam di sekitar Nglanggeran menjadi rusak. Kerusakan yang dialami yaitu tanah yang berada di lahan objek wisata Nglanggeran dan banyak pohon yang berada disana terbabat. Oleh karena itu pihak pengelola ingin memperbaiki kondisi Nglanggeran dengan menekan jumlah wisatawan yang berkunjung (www.Tribunjogja.com). Namun seluruh perubahan system tersebut tidak dibarengi dengan kualitas informasi yang baik sehingga hal ini pun menjadi berpengaruh cukup besar bagi wisatawan.

Berdasarkan keterangan diatas, hal tersebut mengindikasikan bahwa terdapat ketidakpuasan pengunjung. Dimana terjadi beberapa kesalahan dari pengelola obyek wisata yang memberikan ketidak sesuaian antara ekspektasi/harapan pelanggan dengan kinerja/hasil yang diberikan. Ekspektasi wisatawan pada sebuah tempat wisata sangat bergantung pada kualitas pelayanan, kualitas system serta kualitas informasi tentang tempat wisata tersebut sehingga dari hal itu pula akan memberikan rasa percaya dari pengunjung. (Willian H. Delone, 2003) dalam teorinya menjelaskan bahwa kualitas informasi, kualitas sistem, dan kualitas pelayanan adalah factor mendasar yang menentukan kepuasan pelanggan, yang nantinya akan menentukan minat beli ulang atau minat berkunjung kembali.

Beberapa penelitian untuk mengetahui pengaruh kualitas informasi, kualitas sistem dan kualitas pelayanan terhadap kepuasan pelanggan telah dilakukan oleh (Adhitya Rinaldi \& Suryono Budi Santoso, 2018) dari Variabel bebas yang diteliti yang terdiri dari kualitas system, kualitas informasi, kualitas pelayanan secara simultan mempunyai pengaruh positif terhadap kepuasan pelanggan dan minat beli ulang pelanggan traveloka. (Anggraeni \& Madiawati, 2016) dari variable bebas yang diteliti kepercayaan dan kualitas informasi secara simultan berpengaruh positif terhadap keputusan pembelian online.

Berdasarkan latar belakang yang telah dijabarkan sebelumnya, penelitian ini dikembangkan untuk menganalisis minat kunjungan wisata Gunung Api Purba Nglanggeran dengan variable penelitian yang terdiri dari kualitas pelayanan, kualitas informasi, kualitas sistem, kepercayaan serta minat berkunjung.

\section{KAJIAN TEORI}

\section{Kualitas Pelayanan}

Pelayanan dalam kamus umum bahasa Indonesia yaitu menolong, 
menyediakan segala apa yang diperlukan orang lain seperti tamu atau pembelian. Menurut (Kotler, 2012) pelayanan adalah aktivitas atau hasil yang dapat ditawarkan oleh sebuah lembaga kepada pihak lain yang biasanya tidak kasat mata, dan hasilnya tidak dapat dimiliki oleh pihak lain tersebut. Konsep kualitas pelayanan sering dianggap sebagai ukuran relative kesempurnaan atau kebaikan suatu produk/jasa, yang terdiri atas kualitas desain dan kualitas kesesuaian.

Dari uraian yang ada, pelayanan juga dapat diakatakan sebagai suatu bentuk sistem, prosedur atau metode tertentu yang diberikan kepada orang lain. Dalam hal ini, kebutuhan pelanggan tersebut dapat terpenuhi sesuai dengan harapan atau keinginan pelanggan dengan tingkat persepsi mereka. Dalam memenuhi kepuasan konsumen, perusahaan diharuskan secara serius mempertimbangkan faktor-faktor yang memang dibutuhkan guna meraih kepuasan bagi konsumen tersebut.

Kualitas pelayanan dipandang salah satu komponen yang perlu diwujudkan oleh perusahaan karena memiliki pengaruh untuk mendatangkan konsumen baru dan dapat mengurangi kemungkinan pelanggan lama untuk berpindah ke perusahaan lain. Dengan semakin banyaknya pesaing maka akan semakin banyak pilihan bagi konsumen untuk menetapkan pilihan. Hal ini membuat semakin sulit untuk mempertahankan konsumen lama, maka dari itu untuk menangani segala kemungkinan yang bisa saja terjadi sebuah perusahaan harus mampu memberikan salah satu poin tambahan guna mempertahankan konsumen. Salah satu cara tersebut yaitu dengan memberikan pelayanan sebaik mungkin.

Menurut Handayani (2007) dalam (Suhendro, 2017) Kualitas pelayanan pada dasarnya dapat didefinisikan sebagai aktivitas seseorang, sekelompok dan/atau organisasi baik langsung maupun tidak langsung untuk memenuhi kebutuhan.

(Wiratini M et al., 2018) mengemukakan bahwa Kualitas pelayanan dapat dikatakan sebagai perbandingan yang diinginkan atau diharapkan oleh wisatawan sebelum dan setelah mengunjungi suatu obyek wisata. Semakin kecil gap atau perbedaan semakin tinggi kualitas pelayanan yang diberikan dan sebaliknya.

Kualitas pelayanan (service quality) dapat diketahui dengan cara membandingkan persepsi konsumen atas pelayanan yang nyata mereka terima dengan pelayanan yang sesungguhnya mereka harapkan terhadap pelayanan suatu perusahaan. Apabila layanan yang diterima atau dirasakan sesuai dengan yang diharapkan maka kualitas pelayanan dipersepsikan baik dan memuaskan. Jika hal tersebut berbanding terbalik maka kualitas pelayanan dipersepsikan buruk. Dengan demikian, baik tidaknya kualitas sebuah pelayanan tergantung kepada kemampuan penyedia layanan dalam memenuhi harapan pelanggannya secara konsisten.

Banyak perusahaan yang menganggap bahwa kualitas pelayanan adalah proses penyesuaian diri dengan spesifikasi yang dituntut oleh konsumen. Kulitas pelayanan dalam perusahaan akan menimbulkan dampak lanjutan, salah satu contohnya adalah dengan pelayanan yang baik di dalam suatu perusahaan, akan menciptakan kepuasan bagi para 
pelanggannya. Setelah pelanggan merasa puas dengan produk yang diterimannya, pelanggan akan membandingkan pelayanan yang diberikan. Apabila pelangan merasa benar-benar puas, mereka akan membeli ulang serta memberi rekomendasi bagi orang lain agar membeli produk yang sama dari perusahaan tersebut

\section{Kualitas Informasi}

Kualitas informasi dapat diartikan sebagai pengukuran kualitas konten dari sistem informasi, selain itu kualitas informasi merupakan suatu fungsi yang menyangkut nilai dari keluaran informasi yang dihasilkan oleh sistem. Menurut (Rai et al., 2002) Kualitas Informasi, merupakan kualitas keluaran (output) berupa informasi yang dihasilkan oleh sistem informasi yang digunakan.

Menurut James O’Briens (2005) dalam (Septianita et al., 2014) kualitas informasi adalah tingkat dimana informasi memiliki karakteristik isi, bentuk, dan waktu, yang memberikannya nilai buat para pemakai akhir tertentu.

\section{Kualitas Sistem}

Kualitas sistem biasanya berfokus pada karakteristik kinerja sistem. Menurut DeLone dan McLean dalam (Iivari, 2005) kualitas sistem merupakan ciri karakteristik kualitas yang diinginkan dari sistem informasi itu sendiri dan kualitas informasi yang diinginkan informasi karakteristik produk.

Kualitas sistem adalah pengukuran proses sistem informasi yang berfokus pada hasil interaksi antara pengguna dan sistem. Kualitas sistem mempunyai atribut-atribut seperti ketersediaan peralatan, reliabilitas peralatan, kemudahan untuk digunakan, dan waktu respon merupakan faktor penentu mengapa sebuah sistem informasi digunakan atau tidak digunakan (Pawirosumarto, 2016).

\section{Kepercayaan}

Kepercayaan adalah suatu keadaan yang terjadi ketika seorang mitra percaya atas keandalan serta kejujuran mitranya. Kepercayaan melibatkan kesediaan seseorang untuk bertingkah laku tertentu karena keyakinan bahwa mitranya akan memberikan apa yang ia harapkan dan suatu harapan yang umumnya dimiliki seseorang bahwa kata, janji atau pernyataan orang lain dapat dipercaya (Johns et al., 2003).

Menurut (Moorman et al., 1993) kepercayaan didefinisikan sebagai kemauan untuk menyandarkan diri pada hubungan dengan partnernya berlandaskan atas keyakinan.

Sebuah Kepercayaan memiliki unsur keyakinan karena memiliki kredibilitas dan kebajikan. Kredibilitas menunjukkan kepercayaan yang didapat dari pihak lain karena memiliki keahlian yang dikehendaki untuk melakukan suatu tugas, dan kepercayaan yang didapat karena melakukan cara yang baik kepada pihak lain dalam suatu hubungan. Kepercayaan muncul dari kemampuan untuk membuktikan sesuatu, reliabilitas dan intensionalitas. Proses kepercayaan yang diberikan dari perusahaan kepada konsumen ataupun dari pihak lain yang salikng memberi keterkaitan tentu mempunyai manfaat yang banyak.

\section{Minat Berkunjung}

Minat adalah sesuatu yang pribadi dan berhubungan erat dengan sikap. Minat dan sikap merupakan dasar bagi prasangka, dan minat juga penting dalam mengambil keputusan. Menurut 
(Umar, 2003) minat berkunjung kembali merupakan perilaku yang muncul sebagai respon terhadap objek yang menunjukkan keinginan pelanggan untuk melakukan kunjungan ulang. Minat beli muncul akibat dari adanya proses belajar dan proses pemikiran yang kemudian membentuk suatu persepsi.

Menurut Peter dan Olson (2002) dalam (Suwarduki et al., 2016) kaitannya dengan dunia pariwisata, keputusan pembelian diasumsikan sebagai keputusan berkunjung sehingga teori-teori mengenai keputusan pembelian juga digunakan dalam keputusan berkunjung. Keputusan pembelian adalah proses pengintegrasian yang mengkombinasikan pengetahuan untuk mengevaluasi dua atau lebih perilaku alternatif dan memilih salah satu diantaranya.

Minat adalah dorongan untuk memotivasi seseorang melakukan tindakan. Menurut Schiffman dan Kanuk (2007:201) dalam (Gagah Bimo Setyo Putra, Srikandi Kumadji, 2015) mengemukakan bahwa minat membeli merupakan aktivitas psikis yang timbul karena adanya perasaan dan pikiran terhadap suatu barang atau jasa yang diinginkan.

Menurut (Keller, 2008), keputusan pembelian adalah suatu peroses penyelesaian masalah yang terdiri dari menganalisa atau pengenalan kebutuhan dan keinginan, pencairan informasi, penilaian sumber-sumber seleksi terhadap alternatif pembelian, keputusan pembelian, dan prilaku setelah pembelian.

Suatu keputusan dapat dibuat hanya jika ada beberapa alternatif yang dipilih. Apabila alternatif pilihan tidak ada maka tindakan yang dilakukan, tanpa adanya pilihan tersebut tidak dapat dikatakan membuat keputusan.
Preferensi dan niat pembelian tidak selalu menghasilkan pembelian yang aktual. Pengambilan keputusan merupakan suatu kegiatan individu yang secara langsung terlibat dalam mendapatkan dan mempergunakan barang yang ditawarkan. Keputusan pembelian merupakan proses keputusan dimana konsumen benarbenar memutuskan untuk membeli salah satu produk atau jasa diantara berbagai macam alternatif pilihan (Kotler, 2012).

Berdasarkan uraian di atas dapat disimpulkan bahwa keputusan pembelian merupakan kegiatan pemecahan masalah yang dilakukan individu dalam pemilihan alternatif perilaku yang sesuai dari dua alternatif perilaku atau lebih dan dianggap sebagai tindakan yang paling tepat dalam membeli dengan terlebih dahulu melalui tahapan proses pengambilan keputusan.

\section{KERANGKA PIKIR PENELITIAN \& HIPOTESIS}

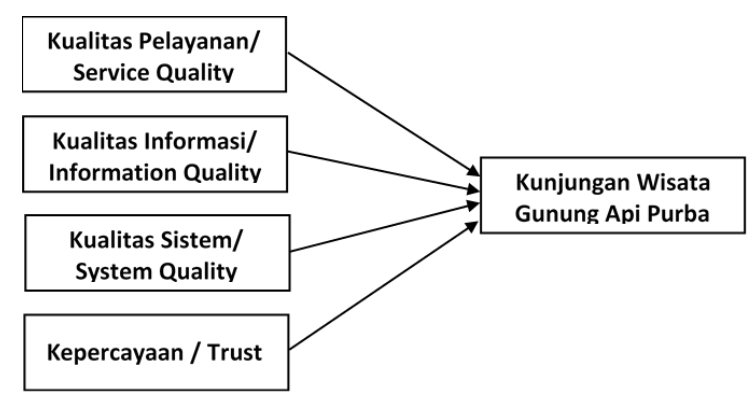

Gambar 2.1 Kerangka Penelitian

\section{Kualitas Pelayanan Berpengaruh Terhadap Minat Berkunjung}

Kualitas pelayanan memiliki andil besar dalam mempengaruhi minat masyarakat pada umumnya. Pelayanan yang prima dan baik dalam sebuah perusahaan akan memberikan kesan bagi para konsumen sehingga 
membuat minat beli akan meningkat dan selalu ingin untuk membeli kembali. Hasil penelitian (Daulay, 2017) di Medan menyatakan bahwa kualitas pelayanan berpengaruh positif signifikan terhadap keputusan pembelian. Hal Ini sejalan dengan penelitan yang dilakukan oleh (Noviana Putra et al., 2016) menunjukkan bahwa kualitas Pelayanan berpengaruh positif dan signifikan terhadap niat berkunjung wisatawan.

Hal ini diperkuat oleh penelitan yang dilakukan oleh (Baharta, 2019), (Ni Kadek Ita Riyanti, I Gusti Agung Ngurah Eka Teja Kusuma, 2020), (Pratama et al., 2021), (Khan \& Su, 2003) memberikan bukti bahwa kualitas pelayanan berpengaruh positif dan signifikan terhadap niat berkunjung wisatawan. Artinya semakin baik kualitas pelayanan yang diberikan oleh pengelola obyek wisata maka minat berkunjung wisatawan akan semakin tinggi.

\section{H1: Kualitas pelayanan berpengaruh positif signifikan terhadap minat berkunjung}

\section{Kualitas Informasi Terhadap Minat Berkunjung}

Kualitas informasi menentukan minat beli, artinya semakin baik kualitas informasi yang meliputi informasi yang akurat, informasi yang dapat dipercaya, informasi yang up to date, informasi sesuai dengan topik bahasan, kemudahan informasi untuk dimengerti, kedetailan informasi dan informasi yang disajikan dalam format desain yang sesuai maka tingkat minat beli semakin tinggi. Hasil penelitian (Jufri, 2019) di Universitas Lampung menghasilkan data bahwa, kualitas informasi berpengaruh positif signifikan terhadap minat beli/berwisata. Hal ini didukung oleh penelitian yang dilakukan oleh (Surya Muhammad Edwin, 2018) menunjukkan bahwa kualitas informasi secara langsung berpengaruh terhadap minat berkunjung wisatawan.

Hasil penelitan yang dilakukan oleh (S. M. Edwin et al., 2019) menemukan bahwa kualitas informasi secara siginifikan mempengaruhi minat wisatawan untuk berkunjung sejalan dengan penelitian ini, hasil penelitian yang dilakukan oleh (Alvianna et al., 2020) menunjukkan bahwa sistem informasi pemasaran mempengaruhi minat kembali berkunjung melalui kepuasan wisatawan yang berkunjung.

H2: Kualitas informasi berpengaruh secara positif dan signifikan terhadap minat berkunjung

\section{Kualitas Sistem Terhadap Minat Berkunjung}

Suatu sistem yang baik harus memberikan kemudahan serta keleluasaan bagi para penggunanya. Selain itu system yang berkualitas juga menjadikan konsumen lebih percaya dengan terjaminnya kepuasan saat mereka membeli sehingga dari hal tersebut akan meningkatkan kepuasan tersendiri dari seitan konsumen. Hasil penelitian (Ta'arufi, 2018) di Yogyakarta menghasilkan data bahwa kualitas sistem berpengaruh positif signifikan terhadap kepuasan berwisata. Sedangkan penelitian yang dilakukan oleh (Yandi \& Septrizola, 2019) menunjukkan bahwa kualitas informasi berpengaruh signifikan terhadap niat beli kembali melalui kepuasan sebagai variabel intervening.

Menurut hasil penelitian yang dilakukan oleh (Zheng et al., 2012) menunjukkan bahwa informasi secara langsung mempengaruhi persepsi individu manfaat dan kepuasan pengguna, yang pada akhirnya 
menentukan niat berkelanjutan pengguna untuk mengkonsumsi dan untuk menyediakan informasi. Hal ini diperkuat oleh penelitian yang dilakukan oleh (Gorla et al., 2010) sistem informasi adalah variabel yang paling berpengaruh terhadap organisasi.

H3: Kualitas sistem berpengaruh positif dan signifikan terhadap kepuasan minat berkunjung

\section{Kepercayaan Terhadap Minat Berkunjung}

Kepercayaan memiliki dampak yang kuat pada keefektifan dan keefisienan relationship marketing. Kepercayaan adalah suatu keadaan yang terjadi ketika seorang mitra percaya atas keandalan serta kejujuran mitranya. Dengan keyakinan bahwa perusahaan atau mitra usaha akan memberikan apa yang sesuai dan dibutuhkan maka hal tersebut akan meningkatkan minat konsumen untuk melakukan keputusan pembelian. Hasil penelitian (Muninggar, 2017) di Yogyakarta menghasilkan data bahwa kepercayaan berpengaruh positif signifikan terhadap keputusan pembelian/berwisata. Hal ini sejalan dengan penelitian yang dilakukan oleh (Susilo et al., 2018) menunjukkan bahwa secara parsial kepercayaan berpengaruh terhadap keputusan berkunjung.

Hal ini didukung Hasil penelitian yang dilakukan oleh (Nugrahaningsih, 2020), (Herwat Setiawan, Hasyim, 2020), (Widodo et al., 2019), (Kesumayuda et al., 2020) menunjukkan bahwa kepercayaan berpengaruh positif dan signifikan terhadap niat berkunjung wisatawan.

H4: Kepercayaan berpengaruh positif terhadap minat berkunjung

\section{METODE PENELITIAN.}

Penelitian ini menggunakan lima variabel. Variabel pertama merupakan variabel independen, yaitu Kualitas pelayanan, variabel kedua variabel Kualitas informasi, variable ketiga merupakan Kualitas system Variabel ke empat kepercayaan, dan variabel kelima merupakan variabel dependen yaitu Niat Kunjungan.

Berdasarkan penelitian ini, yang menjadi populasi dalam adalah seluruh Wisatawan Yang berada di Gunung Api Purba Ngekanggran Gunung kidul yang tidak diketahui Jumlahnya. Sampel dalam penelitian ini 92 Wisatawan Gunung Api Purba Langgeran Gunung Kidul, dengan teknik accidental sampling, menggunakan instrumen kuesioner. Metode yang di gunakan mengguankan metode Formula Lemes how.

\section{HASIL DAN PEMBAHASAN}

\section{Karakteristik Responden}

Karakteristik responden menunjukkan bahwa sebagian besar responden adalah laki-laki (62,2\%). Mayoritas responden berumur 20 tahun - 30 tahun $(39,0 \%)$. Mayoritas responden berpendidikan SLTA/Sederajad (36,6\%). Sebanyak $(80,5 \%)$ responden menyatakan pekerjaannya menuntut kreatifitas tinggi.

Hindari penjelasan tabel dan gambar dengan menggunakan kata "Tabel di atas, gambar di bawah, Tabel berikut, dsb" namun sebutkan tabel secara jelas menggunakan nama seperti Tabel 1, Gambar 2, dsb. Penulisan kata Tabel 1, Gambar 2 harus di cetak tebal. 
Tabel 4.1 Karakteristik Responden

\begin{tabular}{|c|c|c|}
\hline Karakteristik & Frequency & Percent \\
\hline \multicolumn{3}{|c|}{ Jenis Kelamin } \\
\hline Laki-laki & 56 & 62.2 \\
\hline Perempuan & 36 & 37.8 \\
\hline \multicolumn{3}{|c|}{ Usia } \\
\hline Kurang dari 20 Tahun & 4 & 4.9 \\
\hline 20 Tahun -30 Tahun & 32 & 39.0 \\
\hline 31 Tahun - 40 Tahun & 20 & 17.1 \\
\hline 41 Tahun - 50 Tahun & 28 & 29.3 \\
\hline Diatas 50 Tahun & 8 & 9.8 \\
\hline \multicolumn{3}{|l|}{ Status } \\
\hline lajang & 29 & 35,4 \\
\hline Menikah & 63 & 64,6 \\
\hline \multicolumn{3}{|c|}{ Pendidikan } \\
\hline SD & 12 & 14.6 \\
\hline SLTP/ Sederajad & 33 & 34.1 \\
\hline SLTA/ Sederajad & 35 & 36.6 \\
\hline $\mathrm{S} 1 / \mathrm{S} 2 / \mathrm{S} 3$ & 12 & 14.6 \\
\hline
\end{tabular}

Berdasarkan tabel di atas dapat diketahui bahwa seluruh indikator ke empat variabel memiliki nilai $r$ hitung $>\mathrm{r}$ tabel, maka dapat disimpulkan bahwa seluruh item yang digunakan pada penelitian adalah valid. Kemudian hasil uji reliabilitas mennjukkan bahwa nilai cronbach's alpha dari ke empat variabel berada diatas 0,60 maka dapat disimpulkan bahwa seluruh item yang digunakan pada penelitian ini sudah reliabel.

\section{Uji Validitas dan Uji Reliabilitas}

Hasil uji validitas menunjukkan nilai corrected item-total correlation > dari r-table (0.1726) atau valid. Data variabel dalam penelitian ini telah diuji dan memiliki nilai reliabilitas yang baik dengan taraf signifikansi $5 \%$ dan cronbach's alpha based on std. > 0,06

Tabel 4.2 Uji Asumsi Klasik

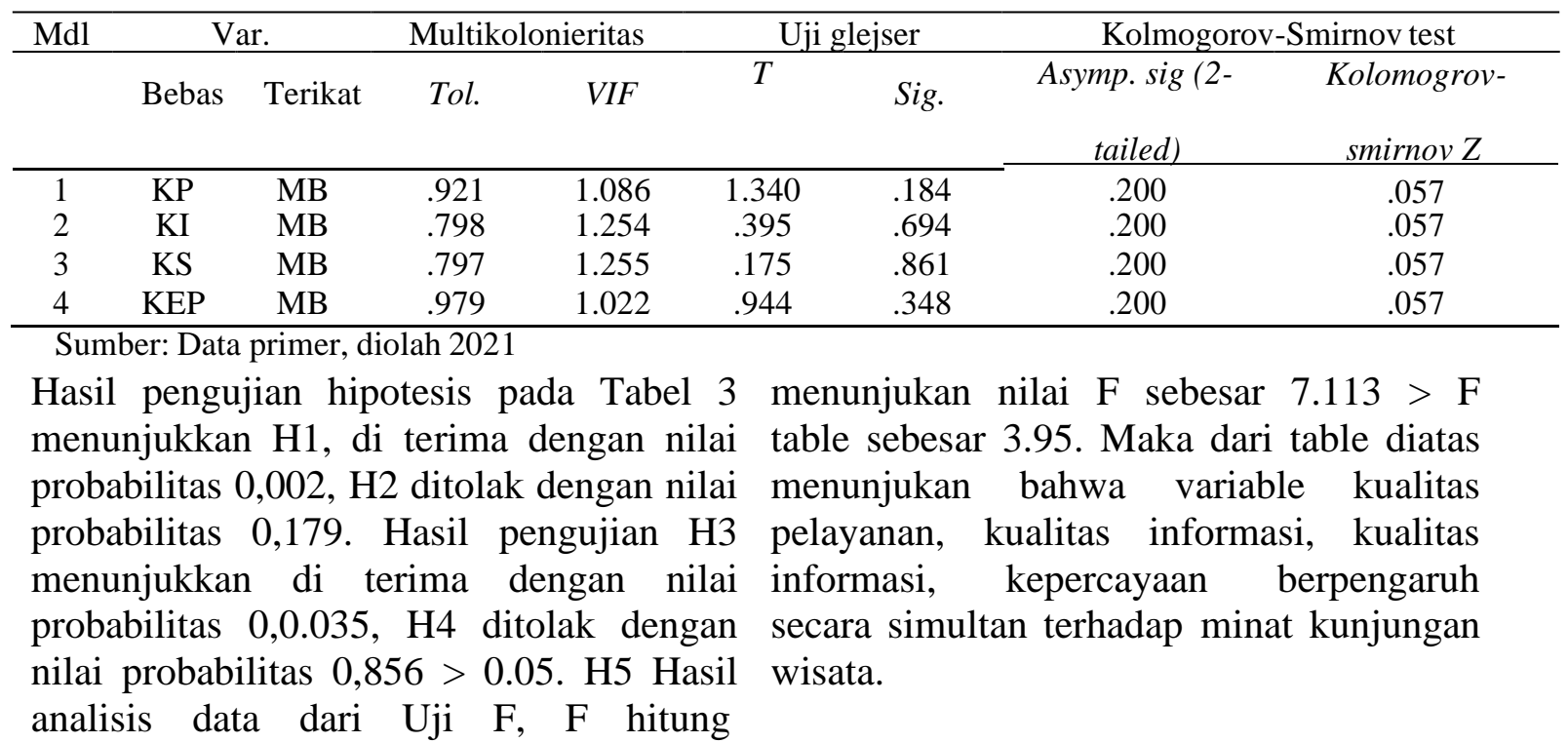




\section{PEMBAHASAN}

Pengujian hipotesis pertama menunjukan terdapat pengaruh yang signifikan kualitas pelayanan terhadap minat berkunjung. Tingkat signifikansi untuk variabel kualitas pelayanan sebesar $0,002 \quad(\mathrm{p}<0,05)$ dan $t$ hitung sebesar 3.227 (positif) maka dapat disimpulkan bahwa $\mathrm{t}$ tabel $<\mathrm{t}$ hitung $(1.662<3.489)$ dan signifikansi $0,002 / 2=0,001<0,05$, responden menyatakan bahwa Tersedia jaminan keamanan bagi pengunjung Objek wisata Gunung Api Purba Nglanggeran. (KP7) dengan rata-rata 4,52 lebih tinggi dari rata-rata yang lain dengan 50 responden menjawab sangat setuju, dan 40 responden menjawab setuju, dan sisanya 2 responden menjawab netral. Sedangkan jawaban terendah pada (KP1) yang Fasilitas yang ada di Objek Wisata Gunung Api Purba Nglanggeran memiliki kualitas yang baik. yaitu dengan rata-rata sebesar 4 dengan 28 responden menjawab sangat setuju, 43 responden menjawab setuju, 9 responden menjawab netral dan sisanya 12 responden menjawab tidak setuju. (Wiratini M et al., 2018) mengemukakan bahwa Kualitas pelayanan dapat dikatakan sebagai perbandingan yang diinginkan atau diharapkan oleh wisatawan sebelum dan setelah mengunjungi suatu obyek wisata. Semakin kecil gap atau perbedaan semakin tinggi kualitas pelayanan yang diberikan dan sebaliknya. Dengan demikian kualitas pelayanan yang di berikan di wisata gunung api purba di nilai wisatawan sudah sangat baik, perlunya peningkatan fasilitas yang ada di kawasan wisata.

Pengujian hipotesis ke dua menunjukan tidak adanya pengaruh

yang signifikan kualitas pelayanan terhadap minat berkunjung. Tingkat signifikansi untuk variabel kualitas informasi sebesar 0,179 ( $p>0,05)$ dan $t$ hitung sebesar 1.356 (positif) maka dapat disimpulkan bahwa $\mathrm{t}$ tabel $>\mathrm{t}$ hitung $(1.662>1.356)$ dan signifikansi $0,179 / 2=0,0895>0,05$, menyatakan bahwa Fasilitas Obyek Wisata Gunung Api Purba Nglanggeran sesuai dengan informasi yang diberikan (KI5) dengan rata-rata 4,30 lebih tinggi dari rata-rata yang lain dengan 36 responden menjawab sangat setuju, 48 responden menjawab setuju dan sisanya 8 responden menjawab netral. Sedangkan jawaban terendah pada (KI3) yang Informasi tentang Gunung Api Purba Nglanggeran mudah dipahami yaitu dengan rata-rata sebesar 3,59 dengan 22 responden menjawab sangat setuju, 35 responden menjawab setuju, 19 responden menjawab netral, 7 responden menjawab tidak setuju dan sisanya 9 responden menjawab sangat tidak setuju. Kualitas informasi dapat diartikan sebagai pengukuran kualitas konten dari sistem informasi, selain itu kualitas informasi merupakan suatu fungsi yang menyangkut nilai dari keluaran informasi yang dihasilkan oleh sistem. Menurut (Rai et al., 2002) Kualitas Informasi, merupakan kualitas keluaran (output) berupa informasi yang dihasilkan oleh sistem informasi yang digunakan. perlunya peningkatan kualitas informasi yang ada di kawasan wisata gunung api purba agar mudah di pahami oleh para wisatawan dengan mudah.

Pengujian hipotesis ke tiga menunjukan adanya pengaruh positif dan signifikan kualitas system terhadap minat berkunjung wisatawan gungung api purba Tingkat signifikansi untuk variabel kualitas sistem sebesar 0,035

$(\mathrm{p}<0,05)$ dan $\mathrm{t}$ hitung sebesar 2.147 (positif) maka dapat disimpulkan

bahwa t tabel $<$ t hitung $(1.662<2.147)$ dan signifikansi 0,035/2=0,0175 $<0,05$. responden menyatakan bahwa Sangat 
mudah bagi pengunjung untuk menjadi ahli dalam menggunakan sistem informasi Obyek Wisata Gunung Api Purba Nglanggeran. (KS4) dengan rata-rata 4,32 lebih tinggi dari rata-rata yang lain dengan 35 responden menjawab sangat setuju, 51 responden menjawab setuju dan sisanya 6 responden menjawab netral. Sedangkan jawaban terendah pada (KS9) yang menyatakan bahwa Sistem informasi Obyek Wisata Gunung Api Purba Nglanggeran fleksibel bagi pengunjung dalam memberikan informasi terkait data aneka wisata yang ada. Yaitu dengan rata-rata sebesar 3,93 dengan 25 responden menjawab sangat setuju, 39 responden menjawab setuju, 25 responden menjawab netral dan sisanya 3 responden menjawab tidak setuju. Kualitas sistem adalah pengukuran proses sistem informasi yang berfokus pada hasil interaksi antara pengguna dan sistem. Kualitas sistem mempunyai atribut-atribut seperti ketersediaan peralatan, reliabilitas peralatan, kemudahan untuk digunakan, dan waktu respon merupakan faktor penentu mengapa sebuah sistem informasi digunakan atau tidak digunakan (Pawirosumarto, 2016). kualitas system yang ada di wisata gunung api purba sudah sangat baik, perlunya peningkatan yang lebih dan konsisten agar lebih meningkat lagi.

Pengujian hipotesis ke empat meunjukan kepercayaan tidak

\section{SIMPULAN DAN SARAN}

Penelitian menghasilan temuan bahwa Terdapat pengaruh yang signifikan kualitas pelayanan terhadap minat berkunjung. Terdapat pengaruh yang tidak signifikan kualitas informasi terhadap minat berkunjung. Terdapat pengaruh signifikan kualitas sistem terhadap minat berkunjung. Terdapat berpengaruh positif dan signifikan terhadap minat berkunjung. Tingkat signifikansi untuk variabel kepercayaan sebesar 0,846 ( $p>0,05)$ dan $t$ hitung sebesar -0.194 (negatif) maka dapat disimpulkan bahwa $\mathrm{t}$ tabel $>\mathrm{t}$ hitung $(1.662>-0.194)$ dan signifikansi $0,846 / 2=0,423>0,05$. responden menyatakan bahwa Saya yakin pengelola Obyek Wisata Gunung Api Purba Nglanggeran akan memberikan kualitas semaksimal mungkin demi kepuasan pengunjung (KEP4) dengan rata-rata 4,12 lebih tinggi dari rata-rata yang lain dengan 33 responden menjawab sangat setuju, 39 responden menjawab setuju, 30 responden menjawab netral dan sisanya 2 responden menjawab tidak setuju.Sedangkan jawaban terendah pada (KEP1) yang menyatakan bahwa Saya merasa pengelola Obyek Wisata Gunung Api Purba Nglanggeran mempunyai reputasi yang bagus. yaitu dengan rata-rata sebesar 3,70 dengan 12 responden menjawab sangat setuju, 43 responden menjawab setuju, 35 responden menjawab netral, 1 responden menjawab tidak setuju dan sisanya 1 responden menjawab sangat tidak setuju. Kepercayaan adalah suatu keadaan yang terjadi ketika seorang mitra percaya atas keandalan serta kejujuran mitranya. Kepercayaan melibatkan kesediaan seseorang untuk bertingkah.

pengaruh yang tidak signifikan kualitas kepercayaan terhadap minat berkunjung. Terdapat pengaruh kualitas pelayanan, kualitas informasi, kualitas system, kualitas kepercayaan secara simultan terhadap minat berkunjung.

Saran: 


\begin{abstract}
Bagi Pengelola Wisata Gunung api purba hendaknya meningkatkan kualitas fasilitas yang ada di obyek wisata gunung api purba agar wisatawan merasa nyaman pada saat berkunjung. Meningkatkan kualitas informasi agar wisatawan mudah memahami informasi yang ada di gunung api purba. Kualitas kepercayaan dalam hal meningkatkan pelayanan agar terus lebih baik lagi, agar wisatawan yang akan berkunjung akan merasa nyaman, dan akan kembali berkunjung ke wisata gunung api purba lagi.
\end{abstract}

\section{DAFTAR PUSTAKA}

Adhitya Rinaldi, \& Suryono Budi Santoso. (2018). Analisis Pengaruh Kualitas Informasi, Kualitas Sistem Dan Kualitas Pelayanan Terhadap Minat Beli Ulang Dengan Kepuasan Pelanggan Sebagai Variabel Intervening (Studi Pada Pelanggan Traveloka Di Kota Semarang). Diponegoro Journal Of Management, $\quad 7(2), \quad 1-14$. Https://Ejournal3.Undip.Ac.Id/Index.Php/Dj om/Article/View/20901

Alvianna, S., Earlike, F., Sani, A., Lasarudin, A., \& Hidayatullah, S. (2020). The Impact Of Visitor Satisfaction Mediation From The Relationship Between Marketing Information Systems, Tourist Destinations And Service Quality Towards Returning Interest In Malang Topeng Village Tourism Destinations. East African Scholars Multidiscip Bull, 12, 332-338. Https://Doi.Org/10.36349/Easjmb.2020.V03i 12.003

Anggraeni, P., \& Madiawati, P. N. (2016). Pengaruh Kepercayaan Dan Kualitas Informasi Terhadap Keputusan Pembelian Secara Online Pada Situs Www.Traveloka.Com. E-Proceeding Of Management :, 3(2), 1880-1887.

Baharta, E. (2019). Pengaruh Kualitas Pelayanan Terhadap Keputusan Berkunjung Kembali (Revisit Intenion) Wisatawan Ke Pesona Alam Puncak. Jurnal Akrab Juara, 4(2), 225-240.
Berkowitz, L., \& Heimer, K. (1989). On The Construction Of The Anger Experience: Aversive Events And Negative Priming In The Formation Of Feelings. Advances In Experimental Social Psychology, 22(C), 1$37 . \quad H t t p s: / / D o i . O r g / 10.1016 / S 0065-$ 2601(08)60304-4

Daulay, N. (2017). Pengaruh Kualitas Pelayanan Dan Kualitas Produk Terhadap Keputusan Pembelian (Studi Kasus Pada Ayam Penyet Surabaya Jl. Dr. Mansyur Medan) (Vol. 2).

Edwin, S. M., Wibowo, W. C., \& Shihab, M. R. (2019). The Effects Of Tourism Information Quality In Shaping Tourists' Visiting Interest. Journal of Physics: Conference Series, 1, 1-6. Https://Doi.Org/10.1088/17426596/1193/1/012011

Edwin, Surya Muhammad. (2018). Analisis Pengaruh Kualitas Informasi Destinasi Wisata Terhadap Minat Berkunjung Wisatawan Dengan Mneggunakan Informastion Quality Framework \& Destination Image Model: Studi Kasus Situs Www.Wakatobitourism.Com.

Gagah Bimo Setyo Putra, Srikandi Kumadji, K. H. (2015). Pengaruh Citra Perusahaan Terhadap Minat Berkunjung Dan Keputusan Berkunjung (Survei Pada Pengunjung Taman Rekreasi Pt.Selecta, Kota Batu, Jawa Timur). Jurnal Administrasi Bisnis, 26(2), 1-8.

Gorla, N., Somers, T. M., \& Wong, B. (2010). Organizational Impact Of System Quality, Information Quality, And Service Quality. Journal Of Strategic Information Systems, 19(3), 207-228. Https://Doi.Org/10.1016/J.Jsis.2010.05.001

Herwat Setiawan, Hasyim, R. M. (2020). Marketing Mix And Trust As A Visiting Intention Factors. Journal Of Multidisciplinary Academic, 04(06), 373380.

Iivari, J. (2005). An Empirical Test Of The Delone-Mclean Model Of Information System Success. Data Base For Advances In Information Systems, 36(2), 8-27. Https://Doi.Org/10.1145/1066149.1066152

Jamalina, I. A., \& Wardani, D. T. K. (2017). 
Strategi Pengembangan Ekowisata Melalui Konsep Community Based Tourism (Cbt) Dan Manfaat Sosial Dan Ekonomi Bagi Masyarakat Di Desa Wisata Nglanggeran, Patuk, Gunung Kidul. Jurnal Ekonomi \& Studi Pembangunan, 18(1), 71-85. Https://Doi.Org/10.18196/Jesp.18.1.4008

Johns, M. M. E., Barnes, M., \& Florencio, P. S. (2003). Restoring Balance To IndustryAcademia Relationships In An Era Of Institutional Financial Conflicts Of Interest: Promoting Research While Maintaining Trust. Journal of The American Medical Association, 289(6), 741-746. Https://Doi.Org/10.1001/Jama.289.6.741

Jufri, M. (2019). Pengaruh Kualitas Informasi, Kualitas Interaksi Layanan Dan Kualitas Usabilityterhadap Minat Beli (Studi Kasus Pada Mahasiswa Pengguna Bukalapak.Com Di Fakultas Ilmu Sosial Dan Ilmu Politik Universitas Lampung.

Keller, K. D. (2008). Manajemen Pemasaran. Pt. Indeks.

Kesumayuda, P., Ms, M., \& Rouly, D. (2020). The Impact Of E-Wom On Trust And Interest Visiting The Destination Of Pahawang Island Tourism, Pesawaran District. Ssrg International Journal of Economics And Management Studies, 7(10), 50-54. Https://Doi.Org/10.14445/23939125/IjemsV7i10p109

Khan, M. M., \& Su, K. D. (2003). Service Quality Expectations Of Travellers Visiting Cheju Island In Korea. Journal Of Ecotourism, 2(2),

114-125. Https://Doi.Org/10.1080/1472404030866813 8

Kotler, P. (2012). Marketing Management (14th Ed.). Pearson Education.

Moorman, C., Deshpande, R., \& Zaltman, G. (1993). Factors Affecting Trust In Market Research Relationships. Journal Of Marketing, 57(1), 81-101. Http://Www.Jstor.Org/Stable/1252059

Muninggar, T. J. (2017). Pengaruh Kualitas Pelayanan Dan Kepercayaan Konsumen Terhadap Keputusan Pembelian (Studi Kasus Pada Konsumen Cuci Mobil Hidrolik Jitas Thoro Purbalingga). Http://Repositorio.Unan.Edu.Ni/2986/1/5624
.Pdf\%0ahttp://Fiskal.Kemenkeu.Go.Id/Ejour nal\%0ahttp://Dx.Doi.Org/10.1016/J.Cirp.201 6.06.001\%0ahttp://Dx.Doi.Org/10.1016/J.Po wtec.2016.12.055\%0ahttps://Doi.Org/10.101 6/J.Ijfatigue.2019.02.006\%0ahttps://Doi.Org/ 10.1

Ni Kadek Ita Riyanti, I Gusti Agung Ngurah Eka Teja Kusuma, I. G. R. (2020). Pengaruh Kualitas Pelayanan, Harga, Dan Promosi Terhadap Niat Berkunjung Kembali Di Villa Rendezvous Bali. Widya Amerta Jurnal Manajemen Fak. Ekonomi, 7(1), 84-99.

Noviana Putra, I. G., Sudiarta, I. N., \& Sasrawan Mananda, I. G. (2016). Pengaruh Kualitas Pelayanan Dan Kepuasan Terhadap Niat Berkunjung Kembali Wisatawan Mancanegara Ke Daya Tarik Wisata Alas Pala Sangeh. Jurnal Ipta, 4(2), 1. Https://Doi.Org/10.24843/Ipta.2016.V04.I02. P01

Nugrahaningsih, H. (2020). Pengaruh Media Sosial Dan Fasilitas Terhadap Minat Pengunjung Dengan Kepercayaan Sebagai Variabel Moderating (Pada Wisata Hutan Mangrove, Pantai Indah Kapuk Jakarta Utara). Media Manajemen Jasa, 8(1), 1-10.

Pawirosumarto, S. (2016). Pengaruh Kualitas Sistem, Kualitas Informasi, Dan Kualitas Layanan Terhadap Kepuasan Pengguna Sistem E-Learning. Jurnal Ilmiah Manajemen, Vi(3), 416-433.

Pratama, B. P., Hidayatullah, S., \& Alvianna, S. (2021). Mediation Effect Of Customer Satisfaction From The Relationship Between System Quality, Information Quality, And Service Quality Towards Interests Of Tourist Visiting In East Java Park 3. International Journal Of Innovative Science And Research Technology, 6(1), 95-100.

Rai, A., Lang, S. S., \& Welker, R. B. (2002). Assessing The Validity Of Is Success Models: An Empirical Test And Theoretical Analysis. Information Systems Research, 13(1), 50-69. Https://Doi.Org/10.1287/Isre.13.1.50.96

Sari, I. P. (2016). Strategi Pengembangan Potensi Kawasan Ekowisata Gunung Api Purba Sebagai Destinasi Ekowisata Di Yogyakarta.

Schiffman, K. (2007). Perilaku Konsumen 
(Kedua). Gramedia.

Septianita, Wi., Agus Winarno, W., \& Arif, A. (2014). Pengaruh Kualitas Sistem , Kualitas Informasi , Kualitas Pelayanan Rail Ticketing System ( Rts ) Terhadap Kepuasan Pengguna ( Studi Empiris Pada Pt . Kereta Api Indonesia ( Persero ) Daop 9 Jember ). E-Journal Ekonomi Bisnis Dan Akuntansi, 1(1), 53-56.

Suhendro, D. (2017). Pengaruh Kualitas Sistem, Kualitas Informasi, Kualitas Pelayanan Dan Ekspektasi Kinerja Terhadap Kepuasan Pengguna Dalam Penerapan Sistem Teknologi Informasi Pada Koperasi Di Kota Pematangsiantar. Jurasik (Jurnal Riset Sistem Informasi Dan Teknik Informatika), 1(1), 33-40. Https://Doi.Org/10.30645/Jurasik.V1i1.6

Susilo, H., Haryono, A. T., \& Mukery, M. (2018). Analisis Pengaruh Harga, Kualitas Pelayanan, Promos, Dan Kepercayaan Terhadap Kepuasan Konsumen Dengan Keputusan Berkunjung Sebagai Variabel Intervening Di Hotel Amanda Hills Bandungan. Jurnal Manajemen Unpad, 8(4), $1-20$.

Http://Jurnal.Unpand.Ac.Id/Index.Php/Ms/Ar ticle/View/989

Suwarduki, P., Yulianto, E., \& Mawardi, M. (2016). Pengaruh Electronic Word Of Mouth Terhadap Citra Destinasi Serta Dampaknya Pada Minat Dan Keputusan Berkunjung (Survei Pada Followers Aktif Akun Instagram Indtravel Yang Telah Mengunjungi Destinasi Wisata Di Indonesia). Jurnal Administrasi Bisnis, 37(2), 1-10.

Ta'arufi, U. (2018). Pengaruh Kualitas Sistem , Informasi , Pelayanan Rail Ticketing System ( Rts ) Terhadap Kepuasan Dan Loyalitas Pelanggan Pt . Kereta Api Indonesia Daop 6 Yogyakarta Yogyakarta. In Fakultas Ekonomi.

Https://Dspace.Uii.Ac.Id/Bitstream/Handle/1 23456789/12585/Skripsi

2.Pdf?Sequence $=1 \&$ Isallowed $=\mathrm{Y}$
Umar, H. (2003). Riset Pemasaran Dan Perilaku Konsumen. Gramedia Pustaka Utama.

Widodo, A., Yusiana, R., \& Aqmarina, F. N. (2019). Stimulus Of Social Media Instagram; The Influence Of Electronic Word Of Mouth Towards Visiting Interest In The Lodge Maribaya Through Trust As Mediation Variable (Study On Instagram Users In Bandung). Ssrn Electronic Journal. Https://Doi.Org/10.2139/Ssrn.3353191

Willian H. Delone, E. R. M. (2003). The Delone And Mclean Model Of Information Systems Success: A Ten-Year Update. Journal of Management Information Systems, 19(4), 930.

Http:/Www.Tandfonline.Com/Doi/Full/10.2 753/Mis0742-

1222290401\%0ahttp://Www.Sciencedirect.C om/Science/Article/B6w4g-4b6sk9r4/2/52c2f579f2408a886c6896e9e9f50391\%5 cnhttp://Www.Sciencedirect.Com/Science/A rticle/Pii/S0740624x03000790\%0ahttp://Ww w.Tandfonline

Wiratini M, N. N. A., Setiawan, N. D., \& Yuliarmi, N. N. (2018). Analisis Faktor-Faktor Yang Mempengaruhi Niat Kunjungan Kembali Wisatawan Pada Daya Tarik Wisata Di Kabupaten Badung. E-Jurnal Ekonomi Dan Bisnis Universitas Udayana, 1, 279-308. Https://Doi.Org/10.24843/Eeb.2018.V07.I01. P10

Yandi, D. R., \& Septrizola, W. (2019). Pengaruh Kualitas Informasi, Kualitas Sistem, Dan Kualitas Layanan Terhadap Minat Beli Ulang Pengguna E-Commerce Situs Blibli.Com Dengan Kepuasan Sebagai Variabel Intervening Pada Masyarakat Kota Padang Deri. Jurnal Kajian Manajemen Dan Wirausaha, 01(03), 67-77.

Zheng, Y., Zhao, K., \& Stylianou, A. (2012). The Impacts Of Information Quality And System Quality On Users' Continuance Intention In Information-Exchange Virtual Communities: An Empirical Investigation. Decision Support Systems, 1, 1-12. Https://Doi.Org/10.1016/J.Dss.2012.11.008 